\title{
Differential gene expression in growth factors, epithelial mesenchymal transition and chemotaxis in the diffuse type compared with the intestinal type of gastric cancer
}

\author{
MARTINE PERROT-APPLANAT ${ }^{1}$, SOPHIE VACHER ${ }^{2}$, CYNTHIA PIMPIE $^{1}$, \\ WALID CHEMLALI ${ }^{2}$, SIMON DERIEUX $^{3}$, MARC POCARD $^{1,3 *}$ and IVAN BIECHE ${ }^{2 *}$
}

\begin{abstract}
${ }^{1}$ INSERM U965, Lariboisiere Hospital, University of Paris-Diderot-Paris 7, 75010 Paris; ${ }^{2}$ Department of Genetics, Pharmacogenomics Unit-Institut Curie, University of Paris-Descartes-Paris 5, 75005 Paris; ${ }^{3}$ Department of Digestive and Oncology Surgery-Lariboisiere Hospital, University of Paris-Diderot-Paris 7, 75010 Paris, France
\end{abstract}

Received November 5, 2018; Accepted March 21, 2019

DOI: $10.3892 / \mathrm{ol} .2019 .10392$

\begin{abstract}
Gastric cancer (GC) is a highly heterogeneous disease and one of the major causes of cancer-related mortality worldwide. Diffuse-type gastric adenocarcinoma (or poorly cohesive- with independent cells) is characterized by aggressive behavior (rapid invasion, chemoresistance and peritoneal metastasis), as compared with intestinal-subtype adenocarcinoma. Diffuse subtype GC additionally has a substantially increasing incidence rate in Europe and the USA, and was often associated with younger age. Our objective was to analyze the expression and clinical significance of genes involved in several signaling pathways in diffuse-type GC. Tumors samples and non-malignant gastric tissues were obtained from patients with GC (diffuse-type and intestinal-subtype adenocarcinoma). The expression of 33 genes coding for proteins involved in four categories, growth factors and receptors, epithelial-mesenchymal transition, cell proliferation and migration, and angiogenesis was determined by reverse transcription-quantitative polymerase chain reaction. The expression of 22 genes was significantly upregulated in diffuse-type GC and two were downregulated (including $\mathrm{CDHI}$ ) compared with normal tissues. Among these genes, acompared with intestinal-subtype adenocarcinoma, diffuse-type GC revealed elevated levels of IGFI
\end{abstract}

Correspondence to: Dr Martine Perrot-Applanat, INSERM U965, Lariboisiere Hospital, University of Paris-Diderot-Paris 7, 41 Boulevard de la Chapelle, Paris 75010, France

E-mail: martine.applanat@inserm.fr

${ }^{*}$ Contributed equally

Abbreviations: GC, gastric cancer; diffuse-GC, diffuse gastric cancer; EMT, epithelial-mesenchymal transition

Key words: GC, diffuse-subtype, intestinal subtype, gene expression profiling, growth factors, EMT, migration, metastasis and IGFIR, FGF7 and FGFRI, ZEB2, CXCR4, CXCL12 and RHOA, and decreased levels of CDH1, MMP9 and MKI67. The expression of selected genes was compared with other genes and according to clinical parameters. Furthermore, $T G F-\beta$ expression was significantly increased in linitis, a sub-population of diffusely infiltrating type associated with extensive fibrosis and tumor invasion. Our study identified new target genes (IGF1, FGF7, CXCR4,TG- $\beta$ and ZEB2) whose expression is associated with aggressive phenotype of diffuse-type GC.

\section{Introduction}

Gastric cancer (GC) is the third leading cause of cancer mortality worldwide in 2012, responsible for 723,000 deaths (1), with high incidence in Asia (2). The vast majority (about 95\%) of gastric tumors are adenocarcinomas, which can be further histologically classified into intestinal, diffuse and mixed types according to the Lauren classification (3). The classification proposed by the World Health Organization divides GCs into well to moderately differentiated, and poorly differentiated (4). Intestinal subtype GCs are a well differentiated and clustered sub-type, while diffuse-type is poorly differentiated, infiltrating and scattered. Poorly cohesive gastric carcinoma, also considered as diffuse GC, include signet-ring cells (SRCC) and other types of poorly cohesive GC.

The incidence, distribution and characteristics of histological subtypes of GC may vary across the globe. During the last 50 years, the incidence and the mortality of GC have declined worldwide, especially in developed countries (5). This decline has primarily included the intestinal type. The intestinal-type GC predominates in high risk geographic areas, such as East Asia, particularly in Japan and Korea, and its incidence increases with age. In contrast, the diffuse-type is more uniformly distributed geographically, but with an increasing incidence in the USA and in Europe $(6,7)$, especially the SRCC (signet-ring cell carcinoma) $(8,9)$. The prognosis of diffuse adenocarcinoma has been debated and depends on the stage of the cancer. For early GC, i.e., not extending beyond 
the submucosa (mostly described in Asian countries), it is clearly established that the prognosis of SRC-type is better than that of non-SRC adenocarcinoma (10-15), probably because the SRC-type tumor is more frequently confined to the mucosa and shows a lower rate of metastasis. In contrast, numerous studies from Asia and a few studies in Europe have demonstrated that diffuse-type GC was more frequently diagnosed at a later stage, with a high proportion of such tumors invading sub-serosa or serosa with lymph node metastasis, and was associated with poorer overall survival (16-18).

The diffuse sub-population of GC is apparently unrelated to Helicobacter Pylori (H. pylori) and develops from morphologically normal gastric mucosa without atrophic gastritis; in contrast the intestinal-type GC that arises from chronic atrophic gastritis and is associated with infectious agents including H. pylori and Epstein-Barr virus (EBV) (19). Interest has recently focused on a subgroup of younger patients (aged $<35$ years, 1/1 sex ratio) with higher incidence of diffuse tumor type by the Lauren classification $(13,20)$. At diagnosis, positive axillary node ( $83 \%$ vs. $6 \%$ in intestinal-type) and peritoneal carcinomatosis ( $18.6 \%$ vs. $6 \%$ in intestinal-type) are present $(13,20)$. Patients are usually treated when the cancer is at an advanced stage. They are generally refractory to conventional therapeutic approaches and their tumors are often associated with recurrence, chemioresistance $(18,21,22)$. Therefore, molecular characterization and gene expression profile of diffuse-type GC, especially those with infiltrating and scattered growth, are critical for identifying candidate players in GC progression.

GC is a complex and molecular heterogeneous disease involving genetic instability and notable epigenetic modifications (DNA methylation, microRNA and histone modifications) that have critical roles in gastric tumorigenesis. A robust molecular classification of GC was performed by the Cancer Genome Atlas (TCGA) project (23). GC were classified into four different molecular subtypes: EBV (9\%), MSI (22\%), genomically stable (20\%), and chromosomal instability (50\%). A small minority of GCs among the genomically stable GC was associated with germline mutations in $\mathrm{CDHl}$ (E-cadherin, a well-known suppressor of invasion/metastasis) or in $R H O A$, and correspond to the diffuse histological subtype $(23,24)$. There are few studies that report signaling pathways in diffuse-subtype GCs (such as hedgehog-EMT pathway, Wnt/ $\beta$ catenin signaling) or genes located downstream PI3K/Akt $(2,15)$. Based on expression patterns 3 molecular sub-types of GC were also defined: proliferative, metabolic and mesenchymal (25). Our objective was to analyze molecular characteristics of a French cohort of diffuse-type GC.

To compare signaling pathways in GC subpopulations and identify new therapeutic targets for diffuse-type GCs, we used quantitative RT-PCR assays of 29 gastric tumor samples to quantify the mRNA expression of 33 genes. The list of genes was selected from the literature (from PubMed/Medline) to be involved in various digestive tumorigenesis and altered (mainly at the transcriptional level) in various cancers. We also included genes reported to be involved in diffuse-GCs according to Lauren classification, schirrous/linitis GC, lymph node metastasis. The 33 genes encode proteins involved in cell categories including growth factors and receptors, epithe- lial-mesenchymal transition (EMT), cell proliferation and migration, and angiogenesis. Furthermore, we compared the expression of each gene with clinico-pathological parameters in each subpopulation of GCs.

\section{Materials and methods}

Patients and tissue samples. A total of 29 patients underwent partial gastrectomy for histopathologically-confirmed gastric adenocarcinoma primary tumor tissue in the Lariboisiere Hospital (Paris, France) from 2005 to 2014. All patients provided written informed consent prior to their inclusion in the study. Biopsies were taken for diagnosis purposes (provided before 2014) and the present study was approved by the Ethical Committee of Lariboisiere Hospital (Paris, France). Eligibility criteria included: i) gastric carcinoma identified by histopathological examination; ii) no other malignancy; iii) no pre-operative chemotherapy or radiotherapy, and iv) availability of complete clinical, histological and biological data. The histological type and the number of positive axillary nodes were determined at the time of surgery. Normal (non-malignant) samples refer to samples harvested from the stomach, from sites distant from the tumor. Immediately after surgery, fresh gastric tumors and their matched normal mucosa were stored in liquid nitrogen until mRNA extraction; other tumor samples and their adjacent normal tissues were routinely fixed in $10 \%$ buffered formalin and embedded in paraffin for histological analysis. The population was divided into two groups according to the histological status of GC: intestinal-subtype adenocarcinoma $(n=16)$ or diffuse subtype adenocarcinoma $(n=13)$ according to the Lauren Classification (Table I). A diffusely infiltrating type of poorly differentiated gastric carcinoma associated with extensive stromal fibrosis, called Linitis plastic carcinoma (26), was also included in the study. The malignancy of infiltrating carcinomas was scored according to TNM staging system (Stage I to IV) first according to AJCC7 $(27)$, revised from IGCA $(28,29)$ and AJCC8 (30). This TNM staging includes T score in the primary tumor (T1-T4), N score (lymph node metastasis, N1-N3 including $\mathrm{pN} 3 \mathrm{a}$ and $\mathrm{pN} 3 \mathrm{~b})$ and $\mathrm{M}$ (metastatic disease).

Total RNA preparation and reverse transcription-quantitative polymerase chain reaction (RT-qPCR). RNA extraction, cDNA synthesis and PCR conditions were as described elsewhere $(31,32)$. The theoretical and practical aspects of real-time quantitative PCR have been described in detail elsewhere (31), using ABI Prism 7900 Sequence Detection System (Applied Biosystems; Thermo Fisher Scientific, Inc., Waltham, MA, USA). The precise amount of total RNA added to each reaction mix (based on optical density) and its quality (lack of extensive degradation) are both difficult to assess. Therefore, we quantified transcripts of 3 endogenous RNA control genes involved in various cellular metabolic pathways, namely TBP (32), (Genbank accession NM_003194), which encodes the TATA box-binding protein (a component of the DNA-binding protein complex TFIID); RPLO (32) (also known as 36B4; NM_001002), which encodes human acidic ribosomal phosphoprotein P0; and PPIA (32), which encodes peptidylprolyl isomerase A (also known as cyclophilin A; NM_021130).

By studying the literature, we selected 33 genes coding for the major proteins known to be involved in cancers such as 
Table I. Clinicopathological characteristics of patients with GC; diffuse-subtype and intestinal-subtype adenocarcinomas.

\begin{tabular}{|c|c|c|c|c|}
\hline $\begin{array}{l}\text { Clincopathological } \\
\text { characteristic }\end{array}$ & Total, $\mathrm{n}=29$ & $\begin{array}{l}\text { Diffuse/poorly cohesive } \\
\mathrm{GC}^{\mathrm{a}}, \mathrm{n}=13(45 \%)\end{array}$ & $\begin{array}{l}\text { Intestinal-subtype } \\
\mathrm{GC}^{\mathrm{b}}, \mathrm{n}=16(55 \%)\end{array}$ & P-value \\
\hline Sex, n $(\%)$ & & & & $0.9^{c}$ \\
\hline Male & $13 / 29$ & $6 / 13(46 \%)$ & $7 / 16(43 \%)$ & \\
\hline Female & $16 / 29$ & $7 / 13(54 \%)$ & $9 / 16(56 \%)$ & \\
\hline Age, years (median) & $63+/-17$ & $57(27-71)$ & $75(59-82)$ & $0.0004^{\mathrm{d}}$ \\
\hline Linitis (presence of fibrosis) & & & & $0.0014^{\mathrm{c}}$ \\
\hline Positive & $9 / 29$ & $8 / 13(61.5 \%)$ & $1 / 16(6 \%)$ & \\
\hline Negative & $20 / 9$ & $5 / 13(38.5 \%)$ & $15 / 16(94 \%)$ & \\
\hline \multicolumn{5}{|l|}{ Tumor size, mm } \\
\hline$<50$ & $10 / 27$ & $4 / 11(36 \%)$ & $6 / 16(37 \%)$ & $0.1^{\mathrm{d}}$ \\
\hline$\geq 50$ & $17 / 27$ & $7 / 11(64 \%)$ & $10 / 16(63 \%)$ & $0.9^{c}$ \\
\hline Depth of tumor invasion $(\mathrm{T})$ & & & & $0.5^{\mathrm{c}}$ \\
\hline $\mathrm{T} 1-\mathrm{T} 2$ & $6 / 29$ & $2 / 13(15 \%)$ & 4/16 (33\%) & \\
\hline $\mathrm{T} 3-\mathrm{T} 4$ & $23 / 29$ & $11 / 13(85 \%)$ & $12 / 16(67 \%)$ & \\
\hline Lymphatic invasion, n (\%) & & & & $0.006^{\mathrm{c}}$ \\
\hline Positive & $16 / 29$ & $11 / 13(85 \%)$ & $5 / 15(33 \%)$ & \\
\hline Negative & $13 / 29$ & $2 / 13(15 \%)$ & $10 / 15(67 \%)$ & \\
\hline \multicolumn{5}{|l|}{ Vascular invasion, $\mathrm{n}+(\%)$} \\
\hline Positive & $20 / 29$ & $10 / 13(77 \%)$ & $10 / 16(62 \%)$ & $0.4^{\mathrm{c}}$ \\
\hline Negative & $9 / 29$ & $3 / 13(23 \%)$ & $6 / 16(38 \%)$ & NS \\
\hline \multicolumn{5}{|l|}{ Neural invasion, n (\%) } \\
\hline Positive & $23 / 29$ & $11 / 13(68 \%)$ & $12 / 16(75 \%)$ & $0.5^{\mathrm{c}}$ \\
\hline Negative & $6 / 29$ & $2 / 13$ & $4 / 16$ & NS \\
\hline Metastasis sites $(\mathrm{M}), \mathrm{n}(\%)$ & & & & $0.033^{\mathrm{c}}$ \\
\hline Peritoneal & $6 / 29$ & $5 / 13(38 \%)$ & $1 / 16(6 \%)$ & \\
\hline Others & $6 / 29$ & 1 (pancreas and colon) & 1 (liver) & \\
\hline
\end{tabular}

${ }^{a}$ Diffuse-type/poorly cohesive adenocarcinoma. ${ }^{b}$ Intestinal-type adenocarcinoma. ${ }^{c} \chi 2,{ }^{d}$ Mann Whitney. NS, not significant; GC, gastric cancer.

growth factors and receptors $(\mathrm{n}=10)$, epithelial-mesenchymal transition (EMT, $n=10)$, cell proliferation and migration $(n=7)$, and angiogenesis $(n=6)$. Among these genes, changes in expression levels of $C D H 1$ (decrease) and of VIM, ZEB2 and $C X C R 4$ (increase) have been previously suggested in diffuse sub-population $(23,33,34)$, while increase in ERBB2 expression was described in intestinal sub-type.

Primers for TBP, RPLLPO, PPIA, and the 33 target genes were chosen with the assistance of the Oligo v.6.0 computer program (National Biosciences, Plymouth, MN, USA). We searched the dbEST and $\mathrm{nr}$ databases to confirm the absence of single nucleotide polymorphisms in the primer sequences and the total gene specificity of the nucleotide sequences chosen as primers. The nucleotide sequence of the primers used to amplify MKI67 and the other 32 (33 with TBP) target genes are available on request.

Each sample was normalized on the basis of its $T B P$ content. Results, expressed as $N$-fold differences in target gene expression relative to the TBP gene and termed "Ntarget" were determined as Ntarget $=2^{\Delta \text { Ctsample }}$, where the $\Delta \mathrm{Ct}$ value of the sample is determined by subtracting the average $\mathrm{Ct}$ value of the target gene from the average $\mathrm{Ct}$ value of the TBP gene $(31,32)$. Preliminary analysis of gene expression have compared basal levels (arbitrary values) in normal samples in the same patients as their tumors (either or diffuse- or intestinal-subtypes). We did not observe changes for most of the genes described in the study (ratio for the median levels ranging from 0.8 to 1.2). The Ntarget values of the samples were subsequently normalized such that the median of the 11 normal gastric tissue Ntarget values was 1 . For each gene, normalized RNA values of 3 or more were considered to represent gene overexpression in tumor samples, and values 0.33 or less represented gene underexpression.

Immunohistochemistry. Immunohistochemical labeling was performed on paraffin sections $(4 \mu \mathrm{m})$, as previously described $(35,36)$. Sections were deparaffinized, rehydrated in graded alcohol, and subjected to antigen retrieval in citrate buffer ( $\mathrm{pH}$ 6.0) in a high pressure cooker. After nonspecific staining had been blocked using a blocking agent, sections were incubated overnight with the anti-IGF1 antibodies (rabbit polyclonal sc-9013; 1:200 dilution; Abcam, Cambridge, UK) at $4^{\circ} \mathrm{C}$ using Ventana Autostainer (Roche Diagnostics, Indianapolis, IN, USA). The antigen-antibody complex was visualized blindly by two specialists including pathologist. 
Statistical analysis. As the mRNA levels of gene expression did not fit a Gaussian distribution, the mRNA levels in each subgroup of samples were characterized by their median values and ranges rather than their mean values and coefficient of variation. For each gene, differences of expression between tumor versus non tumoral gastric tissues (fold change) were analyzed using the Kruskal-Wallis test (36); differences in the number of samples that over- ( $>3$-fold) or and under- $\left(<3\right.$-fold) expressed were analyzed using the $\chi^{2}$ test (36). When indicated, the Mann-Whitney test was used in some studies. The correlations (non parametric Spearman) between expression of genes in GC (poorly cohesive/diffuse adenocarcinoma) were determined. Relationships between expression levels and clinical parameters were analyzed using non parametric Kruskal-Wallis (or Mann-Whitney) and $\chi^{2}$ tests, as indicated in each Table. Statistical analyses were performed using Prism v.5.03 software (GraphPad Software, Inc., La Jolla, CA, USA). $\mathrm{P}<0.05$ was considered to indicate a statistically significant difference.

\section{Results}

Patient's characteristics. The clinicopathological characteristics of the 29 patients of the present study are shown in Table I. The distribution of the gastric tumor subtypes was as follows: diffuse $(n=13)$ and intestinal-subtype $(n=16) \mathrm{GC}$. The median age of patients with diffuse GC was significantly lower 57 (27-71) years as compared with 75 (59-82) years for intestinal-subtype $(\mathrm{P}=0.0004$; Table I). Both sub-types of carcinoma have a great tumor invasion (T3-T4); however, a higher proportion of patients with poorly cohesive GC presented T3-T4 tumor stage. Patients with diffuse adenocarcinoma have more lymphatic invasion (a higher positive axillary node count $)(\mathrm{P}=0.006)$ and metastasis $(\mathrm{P}=0.033)$ than patients with intestinal-subtype (Table I). Vascular and neural invasion were not different (Table I). A sub-population of diffuse GC associated with extensive fibrosis was present in $62 \%$ of the patients (Table I), similar to a previous report (26). In addition, when comparing the TNM stage, diffuse GC was present at TNM stage II, III and IV (38\%, 31\% and $31 \%$ respectively), while intestinal-subtype was more likely stage I, II and III (26\%, 44\% and 25\%).

Expression of 32 target genes and MKI67 in diffuse GCs. We used real-time quantitative RT-qPCR to analyse mRNA expression of 33 target genes in the 13 diffuse GC as compared with the 11 non-tumoral gastric samples (Table II). These target genes were selected from several important signalling pathways known to be involved in cancer such as growth factors and associated proteins $(n=10)$, epithelial-mesenchymal transition (EMT, $\mathrm{n}=10$ ), cell proliferation and migration $(n=7)$, and angiogenesis $(n=6)$. The mRNA levels of the 33 target genes were high in both the non-tumoral and tumoral gastric tissues and were thus reliably measured by real-time RT-qPCR using fluorescence SYBR Green method (cycle threshold, CT<35). mRNA levels in cancers were expressed relative to the median mRNA levels observed in the 11 non-tumoral gastric tissues. Medians and ranges of mRNA levels for the 33 target genes, along with the percentages of overexpression and underexpression, are shown in Table II.
Twenty two genes were significantly up-regulated and 2 genes were down-regulated in diffuse-GC as compared to non-tumoral gastric samples. Up-regulated genes were: i) growth factors: $I G F 1(\mathrm{x} 7.4, \mathrm{P}=0.0004)$ and $I G F 2(\mathrm{P}=0.024)$, IGF2R $(\mathrm{P}=0.0071)$ and IRS1 $(\mathrm{P}=0.0084)$, FGF7 $(\mathrm{P}=0.0019)$ and ERBB2 $(\mathrm{P}=0.0016)$; ii) genes involved in EMT: VIM ( $\mathrm{P}=0.0013)$, SNAII ( $\mathrm{P}=0.0019)$, SNAI2/SLUG ( $\mathrm{x} 3, \mathrm{P}=0.0013)$, TWIST2 $(\mathrm{P}=0.046), T G F \beta 1(\mathrm{P}=0.00003), R U N X 3(\mathrm{P}=0.0065)$, ZEB2 $(\mathrm{P}=0.0005)$, and $C X C R 4$ (x3, $\mathrm{P}=0.0009)$, and iii) migration: $M M P 2$ (x3.2, $\mathrm{P}=0.00006), M M P 9(\mathrm{P}=0.015), S P P 1(\mathrm{x} 4.1$, $\mathrm{P}=0.00006), C D 44$ ( $\mathrm{P}=0.002)$, RHOA ( $\mathrm{P}=0.0026$; Table II). Other dysregulated genes include VEGF-C $(\mathrm{P}=0.0071), N R P 1$ ( $\mathrm{P}=0.00037)$, and MKI67 (x3.8, $\mathrm{P}=0.0008)$; this latter gene encodes the proliferation-related antigen $\mathrm{Ki}-67$. In addition, overexpression ( $>3$-fold) in more than $50 \%$ of the tumors was significant for IGF1 (>75\%), SLUG, CXCR4, MMP2, SPP1, RHOA ( $>75 \%)$ and $M K I 67$, as compared non tumoral gastric tissues (Table II). In contrast, expression of $C D H 1(\mathrm{P}=0.04)$ and VEGFA189 $(\mathrm{P}=0.009)$ were down-regulated in diffuse GC as compared to non-tumoral gastric samples (Table II).

Expression of 32 target genes and MKI67 in intestinal GCs. The expression of the same 33 target genes was then analysed in the series of 16 intestinal sub-type GC. Medians and ranges of mRNA levels for the target genes are shown in Table S1, along with the percentages of overexpression and underexpression. As compared to the non-tumoral tissues, fourteen genes that were significantly up-regulated included IGF2R $(\mathrm{P}=0.0033), \quad E R B B 2 \quad(\mathrm{P}=0.00006)$ and ERBB3 $(\mathrm{P}=0.032)$, SNAII $(\mathrm{P}=0.0005), \quad$ SNAI2/SLUG $(\mathrm{P}=0.0031)$, TGF $\beta 1(\mathrm{P}=0.00003), M M P 2(\mathrm{P}=0.01), M M P 9$ and $S P P 1(\mathrm{x} 15$, $\mathrm{P}<0.0007$ and $\mathrm{x} 5, \mathrm{P}<0.00004$, respectively), $C D 44(\mathrm{P}=0.03)$ and RHOA $(\mathrm{P}=0.03), \operatorname{VEGFC}(\mathrm{P}=0.041)$ and NRPI $(\mathrm{P}=0.023)$, and MKI67 (x8.5, $\mathrm{P}=0.00003$; Table S1). In contrast, expression of IGFIR $(\mathrm{P}=0.034), C X C L 12(\mathrm{P}=0.023)$ and $R H O B$ $(\mathrm{P}=0.0066)$ was significantly decreased (Table $\mathrm{S} 1)$; underexpression ( $>3$-fold decrease) of $C X C L 12$ and $R H O B$ was observed in $44 \%$ of the intestinal-type GC.

Differential expression of genes between the GC subtypes. Comparison of gene expression in diffuse-subtype with respect to intestinal-GC revealed increased levels for $I G F 1$ $(\mathrm{P}=0.0012)$ and IGFIR $(\mathrm{P}=0.044), F G F 7(\mathrm{P}=0.0001)$ and FGFR1 $(\mathrm{P}=0.048)$, ZEB2 $(\mathrm{P}=0.00008)$, CXCR4 $(\mathrm{P}=0.035)$, whereas lower expression of $C D H 1 \quad(\mathrm{P}=0.014), M M P 9$ $(\mathrm{P}=0.018)$ and MKI67 $(\mathrm{P}=0.0057)$ were observed (Table III). We also observed higher level of RHOA in diffuse- sub-type with respect to intestinal-sub-type (x8.7 vs. 2.8, although not significant $\mathrm{P}=0.016$ ), along with $85 \%$ in diffuse sub-type (vs. 50\% in intestinal-subtype) showing RHOA overexpression ( $>3$ fold as compared to normal samples) (Table II and Table S1). The down-regulation of CXCL12 in intestinal adenocarcinoma $(\mathrm{P}=0.013)$ was not observed in the diffuse-subtype GC (Table III).

Correlations between the expressions of five selected genes in diffuse gastric adenocarcinoma. We analysed the expression of five selected genes, IGF1, FGF7, CDH1, ZEB2, and CXCR4 that were mostly dysregulated (over- or under-expression) in poorly cohesive/diffuse GC vs. non-tumoral tissue and other 
Table II. Statistical analysis of mRNA expression of genes in diffuse/poorly cohesive gastric cancers relative to the peri-tumoral tissues.

A, Growth factors and receptors $(n=10)$

\begin{tabular}{lccc}
\hline Genes & Nontumoral gastric tissues $(\mathrm{n}=11)^{\mathrm{b}}$ & ${\text { Diffuse/poorly cohesive carcinoma }(\mathrm{n}=13)^{\mathrm{b}}}^{\mathrm{P}^{\mathrm{b}} \mathrm{value} \mathrm{a}^{\mathrm{a}}}$ \\
\hline IGF1 & $1(0.42-2.93)$ & $7.37(0.97-12.75)$ & 0.00037 \\
IGF2 & $1(046-3.13)$ & $2.26(0.80-19.16)$ & 0.024 \\
IGF1R & $1(0.55-1.46)$ & $1.10(0.63-1.55)$ & $0.79(\mathrm{NS})$ \\
IGF2R & $1(0.79-1.33)$ & $1.43(0.85-1.65)$ & 0.0071 \\
IRS1 & $1(0.59-1.90)$ & $1.50(0.91-2.71)$ & 0.0084 \\
IRS2 & $1(0.62-1.69)$ & $1.13(0.52-4.44)$ & $0.51(\mathrm{NS})$ \\
FGF7 & $1(0.25-2.62)$ & $2.16(1.10-3.45)$ & 0.0019 \\
FGFR1 & $1(0.55-2.95)$ & $1.94(0.96-3.53)$ & $0.060(\mathrm{NS})$ \\
ERRB2 & $1(0.43-1.41)$ & $1.62(0.87-2.74)$ & 0.0016 \\
ERRB3 & $1(0.19-1.70)$ & $0.91(0.51-2.55)$ & $0.98(\mathrm{NS})$ \\
\hline
\end{tabular}

$\mathrm{B}$, EMT and migration $(\mathrm{n}=10)$

\begin{tabular}{lccc}
\hline Genes & Nontumoral gastric tissues $(\mathrm{n}=11)^{\mathrm{b}}$ & ${\text { Diffuse/poorly cohesive carcinoma }(\mathrm{n}=13)^{\mathrm{b}}}^{\mathrm{P}-\mathrm{value} \mathrm{a}^{\mathrm{a}}}$ \\
\hline VIM & $1(0.65-1.64)$ & $1.62(0.88-2.37)$ & 0.0013 \\
CDH1 & $1(0.05-1.22)$ & $0.78(0.01-1.06)$ & 0.04 \\
SNAI1 & $1(0.29-2.07)$ & $2.39(0.90-4.92)$ & 0.0019 \\
SLUG/SNAI2 & $1(0.61-2.0)$ & $3.02(1.15-4.06)$ & 0.0013 \\
TWIST2 & $1(0.58-2.82)$ & $2.30(0.62-3.29)$ & 0.046 \\
TGFB1 & $1(0.47-1.23)$ & $2.05(1.47-4.27)$ & 0.000034 \\
RUNX3 & $1(0.00-2.23)$ & $1.77(0.00-4.91)$ & 0.0065 \\
ZEB2 & $1(0.58-1.41)$ & $1.70(0.84-2.97)$ & 0.00046 \\
CXCR4 & $1(0.47-3.56)$ & $3.14(1.52-7.30)$ & 0.00086 \\
CXCL12 & $1(0.26-3.49)$ & $1.05(0.30-3.19)$ & $0.75(\mathrm{NS})$ \\
\hline
\end{tabular}

C, Cell proliferation and migration $(n=7)$

\begin{tabular}{lccc}
\hline Genes & Nontumoral gastric tissues $(\mathrm{n}=11)^{\mathrm{b}}$ & ${\text { Diffuse/poorly cohesive carcinoma }(\mathrm{n}=13)^{\mathrm{b}}}^{\mathrm{P}^{\mathrm{v}} \mathrm{value} \mathrm{a}^{\mathrm{a}}}$ \\
\hline MMP2 & $1(0.68-1.99)$ & $3.21(1.47-6.15)$ & 0.000057 \\
MMP9 & $1(029-2.76)$ & $2.01(0.92-4.13)$ & 0.015 \\
SPP1 osteopontin & $1(0.43-2.04)$ & $4.12(1.75-89.35$ & 0.000057 \\
CD44 & $1(0.57-1.89)$ & $1.73(1.02-2.81)$ & 0.0019 \\
RHOB & $1(0.30-2.84)$ & $0.52(0.32-1.23)$ & $0.21(\mathrm{NS})$ \\
RHOA & $1(0.05-5.29)$ & $8.65(0.03-20.39)$ & 0.0026 \\
MKI67 & $1(0.1-3.71)$ & $3.76(1.34-10.83)$ & 0.00078 \\
\hline
\end{tabular}

$D$, Angiogenesis $(n=6)$

\begin{tabular}{lccc}
\hline Genes & Nontumoral gastric tissues $(\mathrm{n}=11)^{\mathrm{b}}$ & ${\text { Diffuse/poorly cohesive carcinoma }(\mathrm{n}=13)^{\mathrm{b}}}^{\mathrm{P}-\mathrm{value}{ }^{\mathrm{a}}}$ \\
\hline VEGFA 165 & $1(0.68-1.56)$ & $0.86(0.58-2.09)$ & $0.71(\mathrm{NS})$ \\
VEGFA 189 & $1(0.49-1.63)$ & $0.67(0.42-1.00)$ & 0.0091 \\
FLT1 & $1(0.64-2.20)$ & $1.08(0.62-2.07)$ & $0.91(\mathrm{NS})$ \\
KDR & $1(0.63-2.63)$ & $1.11(0.67-1.47)$ & $0.40(\mathrm{NS})$ \\
VEGFC & $1(0.44-1.57)$ & $1.38(0.86-2.60)$ & 0.0071 \\
NRP1 & $1(0.57-1.87)$ & $1.94(1.21-3.27)$ & 0.00037
\end{tabular}

${ }^{a}$ Mann Whitney's U test. ${ }^{b}$ Median (range) of gene mRNA expression levels. NS, not significant; EMT, epithelial-mesenchymal transition. 
Table III. Statistical analysis of mRNA expression of genes in diffuse/poorly cohesive relative to intestinal-subtype gastric carcinoma.

A, Growth factors and receptors $(n=10)$

\begin{tabular}{lccc}
\hline Genes & $\begin{array}{c}\text { Diffuse/poorly cohesive } \\
\text { adenocarcinoma }(\mathrm{n}=13)^{\mathrm{b}}\end{array}$ & ${\text { Intestinal carcinoma }(\mathrm{n}=16)^{\mathrm{b}}}^{\mathrm{P}-\mathrm{value}}$ \\
\hline IGF1 & $7.37(0.97-12.75)$ & $1.14(0.1-10.09)$ & 0.0012 \\
IGF2 & $2.26(0.80-19.16)$ & $1.51(0.18-6.18)$ & $0.51(\mathrm{NS})$ \\
IGF1R & $1.10(0.63-1.55)$ & $0.60(0.39-9.33)$ & 0.044 \\
IGF2R & $1.43(0.85-1.65)$ & $1.45(0.81-2.63)$ & $0.55(\mathrm{NS})$ \\
IRS1 & $1.50(0.91-2.71)$ & $1.11(0.56-18)$ & $0.079(\mathrm{NS})$ \\
IRS2 & $1,13(0,52-4,44)$ & $0.89(0.15-1.77)$ & $0.10(\mathrm{NS})$ \\
FGF7 & $2.16(1.10-3.45)$ & $0.70(0.07-2.44)$ & 0.00011 \\
FGFR1 & $1.94(0.96-3.53)$ & $1.04(0.31-2.68)$ & 0.048 \\
ERRB2 & $1.62(0.87-2.74)$ & $2.20(1.05-34.55)$ & $0.066(\mathrm{NS})$ \\
ERRB3 & $0.91(0.51-2.55)$ & $1.54(0.59-3.49)$ & $0.066(\mathrm{NS})$ \\
\hline
\end{tabular}

$\mathrm{B}$, EMT and migration $(\mathrm{n}=10)$

\begin{tabular}{lccc}
\hline Genes & $\begin{array}{c}\text { Diffuse/poorly cohesive } \\
\text { adenocarcinoma }(\mathrm{n}=13)^{\mathrm{b}}\end{array}$ & ${\text { Intestinal carcinoma }(\mathrm{n}=16)^{\mathrm{b}}}^{\mathrm{P}-\mathrm{value}}$ \\
\hline VIM & $1.62(0.88-2.37)$ & $1.35(0.48-2.79)$ & $0.072(\mathrm{NS})$ \\
CDH1 & $0.78(0.01-1.06)$ & $1.01(0.29-1.63)$ & 0.014 \\
SNAI1 & $2.39(0.90-4.92)$ & $3.21(0.52-11.62)$ & $0.26(\mathrm{NS})$ \\
SLUG/SNAI2 & $3.02(1.15-4.06)$ & $2.56(1.0-10.50)$ & $1.00(\mathrm{NS})$ \\
TWIST2 & $2.30(0.62-3.29)$ & $1.46(0.12-3.23)$ & $0.087(\mathrm{NS})$ \\
TGFB1 & $2.05(1.47-4.27)$ & $2.17(1.05-6.51)$ & $1.00(\mathrm{NS})$ \\
RUNX3 & $1.77(0.00-4.91)$ & $1.66(0.00-3.98)$ & $0.44(\mathrm{NS})$ \\
ZEB2 & $1.70(0.84-2.97)$ & $0.82(0.27-1.60)$ & 0.000079 \\
CXCR4 & $3.14(1.52-7.30)$ & $1.71(0.5-7.16)$ & 0.035 \\
CXCL12 & $1.05(0.30-3.19)$ & $0.43(0.08-1.86)$ & 0.013 \\
\hline
\end{tabular}

C, Cell proliferation and migration $(n=7)$

\begin{tabular}{lccc}
\hline Genes & $\begin{array}{c}\text { Diffuse/poorly cohesive } \\
\text { adenocarcinoma }(\mathrm{n}=13)^{\mathrm{b}}\end{array}$ & ${\text { Intestinal carcinoma }(\mathrm{n}=16)^{\mathrm{b}}}^{\mathrm{P}}$ & $0.48(\mathrm{NS})$ \\
MMP2 & $3.21(1.47-6.15)$ & $2.99(0.46-7.95)$ & 0.018 \\
MMP9 & $2.01(0.92-4.13)$ & $5.25(0.80-19.27)$ & $0.25(\mathrm{NS})$ \\
SPP1 osteopontin & $4.12(1.75-89.35$ & $14.51(1.06-119.54)$ & $0.20(\mathrm{NS})$ \\
CD44 & $1.73(1.02-2.81)$ & $1.42(0.75-2.55)$ & 0.018 \\
RHOB & $0.52(0.32-1.23)$ & $0.34(0.12-0.93)$ & $0.16(\mathrm{NS})$ \\
RHOA & $8.65(0.03-20.39)$ & $2.79(0.59-23.08)$ & 0.0057 \\
MKI67 & $3.76(1.34-10.83)$ & $8.48(1.83-17.67)$ & \\
\hline
\end{tabular}

$D$, Angiogenesis $(n=6)$

\begin{tabular}{lccr}
\hline Genes & $\begin{array}{c}\text { Diffuse/poorly cohesive } \\
\text { adenocarcinoma }(\mathrm{n}=13)^{\mathrm{b}}\end{array}$ & ${\text { Intestinal carcinoma }(\mathrm{n}=16)^{\mathrm{b}}}^{\mathrm{P}-\mathrm{value}}$ \\
\hline VEGFA 165 & $0.86(0.58-2.09)$ & $1.02(0.69-4.07)$ & $0.15(\mathrm{NS})$ \\
VEGFA 189 & $0.67(0.42-1.00)$ & $0.70(0.30-2.04)$ & $0.46(\mathrm{NS})$ \\
FLT1 & $1.08(0.62-2.07)$ & $1.06(0.43-1.60)$ & $0.90(\mathrm{NS})$ \\
KDR & $1.11(0.67-1.47)$ & $1.12(0.57-1.78)$ & $0.90(\mathrm{NS})$ \\
VEGFC & $1.38(0.86-2.60)$ & $1.63(0.51-3.34)$ & $0.90(\mathrm{NS})$ \\
NRP1 & $1.94(1.21-3.27)$ & $1.71(0.74-4.00)$ & $0.33(\mathrm{NS})$ \\
\hline
\end{tabular}

${ }^{a}$ Mann Whitney's U test. ${ }^{b}$ Median (range) of gene mRNA expression levels. NS, not significant. 
gastric tumors. Correlation analysis (Table IV) show that both $I G F 1$ and $F G F 7$ expression significantly correlated primarily with FGFRI ( $\mathrm{P}=0.027$ and $\mathrm{P}=0.0015$, respectively), several genes involved in EMT including VIM $(\mathrm{P}=0.017$ and $\mathrm{P}=0.007$, respectively), SNAI2/SLUG $(\mathrm{P}=0.007$ and $\mathrm{P}=0.012$, respectively), TWIST2 ( $\mathrm{P}=0.004$ and $\mathrm{P}=0.0005$, respectively), ZEB2 $(\mathrm{P}=0.0011$ and $\mathrm{P}=0.0006$, respectively) and $M M P 2(\mathrm{P}=0.0006$ and $\mathrm{P}=0.0055$, respectively), as well as NRPI ( $\mathrm{P}=0.010$ and $\mathrm{P}=0.001$, respectively). IGF1 expression also correlated with $C D 44$ ( $\mathrm{P}=0.041) . F G F 7$ expression also correlated with $I G F 1$ and $I G F 2(\mathrm{P}=0.012$ and $\mathrm{P}=0.031$, respectively), IRS2 $(\mathrm{P}=0.041)$, RUNX3 $(\mathrm{P}=0.018)$ and CXCL12 $(\mathrm{P}=0.027)$. ZEB2 expression was associated with many genes involved in EMT and migration including VIM ( $\mathrm{P}=0.0024)$, SNAI2/SLUG $(\mathrm{P}=0.0005)$, TWIST2 $(\mathrm{P}<0.0001), T G F \beta \quad(\mathrm{P}=0.049), R U N X 3 \quad(\mathrm{P}=0.046), C X C L 12$ $(\mathrm{P}=0.0017)$, and MMP2 ( $\mathrm{P}=0.009$; Table IV). ZEB2 expression was also associated with $I G F 1(\mathrm{P}=0.0011), F G F 7, F G F R I$ $(\mathrm{P}=0.0006$ and $\mathrm{P}=0.002)$ and $N R P 1(\mathrm{P}=0.005$; Table IV). $C D H 1$ expression was associated with IGF2R $(\mathrm{P}<0.0001)$ and $R H O A$ ( $\mathrm{P}=0.018$; Table IV). No correlation of $C X C R 4$ expression was found with other genes (Table IV).

Comparison of mRNA levels of five dysregulated genes according to clinico-pathological findings in diffuse gastric adenocarcinoma. Diffuse subtype- GC are aggressive adenocarcinoma associated with lymphatic invasion (a higher positive axillary node score) and metastasis, compared with intestinal sub-type (Table I). We further analyzed the relationships between the five selected genes and clinical parameters in diffuse-type GC (Table V). Interestingly, we found that CXCR4 expression was significantly increased with TNM (IIIc-IV vs. II-IIIa, $\mathrm{P}=0.022$ ) and lymphatic invasion (pN2-N3 vs. pN0-N1, $\mathrm{P}=0.05$; Table V). The decrease of $C D H 1$ was associated with tumor invasion (T3-T4) and high TNM stage $(\mathrm{IV}, \mathrm{P}=0.05)$. Increase of $I G F I$ was associated with lymphatic invasion (positive vs. negative), but not with the number of positive lymph nodes. No correlation was found between FGF7 expression and clinical parameters.

TGF $\beta$ expression is increased in a sub-population of diffusely infiltrating gastric carcinoma. Linitis Plastica is a diffusely infiltrating type of diffuse-GC associated with extensive stromal fibrosis (26). In our series of GCs, linitis represents $61 \%$ of the diffuse gastric carcinoma (Table I). These linitis tumors were both larger ( $90 \mathrm{~mm}$ vs. $42 \mathrm{~mm}, \mathrm{P}=0.005)$, had high tumor invasion score (T3-T4) and were associated with fibrosis. The majority of linitis were also graded TNM IV and associated with metastasis (66\%) as compared to other diffusely infiltrating tumors. We then analyzed the expression of TGF $\beta$, a known factor for fibrosis, in diffuse GC. As shown in Table $\mathrm{V}, T G F \beta 1$ expression was significantly correlated with tumor size $(\mathrm{P}=0.004)$ and tumor invasion $(\mathrm{T} 3-\mathrm{T} 4$, $\mathrm{P}=0.05)$. Interestingly, when linitis was compared to other (non-linitis) diffusely infiltrating GC, TGF $\beta 1$ expression was significantly increased ( $\mathrm{x} 2.6$ vs. $1.8, \mathrm{P}=0.04$ ) and positively associated with tumor invasion (T3-T4, $\mathrm{P}=0.004)$.

IGF1 protein is present in diffuse-subtype GC tissues. In line with the objective of the study, we assessed the localization of IGF1 protein using immunohistochemistry on paraffin sections from a total of 29 gastric tumors. Within the diffuse sub-type GC (Fig. 1), IGF1 staining was found in the gastric mucosa (Fig. 1A and B). Within diffuse sub-type GCs such as linitis (associated with fibrosis, Fig. 1C), moderate IGF1 staining was observed in single ring cells (Fig. 1D). Strong IGF1 immunostaining was observed in the most advanced diffuse sub-type GCs (Fig. 1E and F). In contrast, lower staining may be observed in glandular structures in intestinal GC (Fig. S1).

\section{Discussion}

Diffuse-type gastric adenocarcinoma is an aggressive and infiltrating carcinoma with substantially increasing incidence in Europe and USA (6,7). In agreement with previous studies $(13,20,37)$, we found that this diffuse-type GC is more common in younger patients, with similar prevalence in both sexes, and is characterized by late clinical presentation and aggressivity (positive axillary node count and peritoneal carcinomatosis). Using RT-qPCR, we analyzed the expression of 33 selected genes coding for proteins involved in four categories: growth factors, EMT, cell proliferation and migration, and angiogenesis, in a series of 29 gastric tumors. We found that 22 genes were upregulated in the diffuse GC compared to normal gastric tissue. As compared with intestinal-type GC, eleven genes in the diffuse GC showed notable differences in expression. Of these, overexpressed genes are involved in EMT (among which ZEB2), cell migration (CXCR4, RHOB, and $M M P 9)$, or are growth factors (IGF1, IGFIR, FGF7 and FGFR1). An increase of ZEB2, CXCR4 and TGF $\beta 1$, and a decrease of $C D H 1$ were associated with invasion and/or metastasis in diffuse-type GC.

Among GCs, a small minority that are genomically stable have been associated with mutated $C D H 1$ (24) or it loss of expression (38), and by low genomic deletion of RHOA (23). We found a significant decrease of $C D H 1$ expression in diffuse GC as compared with intestinal sub-type $(\mathrm{P}=0.014)$ and non-tumoral gastric tissue $(\mathrm{P}=0.04)$, in agreement with the studies from the group of Sasaki $(33,34)$. Moreover, $C D H 1$ underexpression significantly correlated with tumor invasion (T3-T4, $\mathrm{P}=0.025$ ) and a more advanced stage (IV).

The connection between loss of E-cadherin expression in cancers and passage through an EMT has been established by many studies $(39,40)$. When gene expression profiling was performed for EMT signature genes in diffuse GC, in addition to decrease $\mathrm{CDH} 1$ expression, we identified numerous significant up-regulated genes as compared to non-tumoral gastric tissues, including VIM, SNAII, SLUG, ZEB2, RUNX3, TGF 31 $(\mathrm{P}<0.01)$; in contrast only $S N A I 1, S L U G$ and $T G F \beta 1$ were dysregulated in intestinal-subtype GC. Our results suggested that mesenchymal features are more prominent in diffuse GC, resulting in tumor aggressiveness of this subgroup of GC. The overexpression of TWIST2, as also observed in diffuse-GC $(\mathrm{P}=0.046)$, extends previous observations on the overexpression of TWIST in gastric and lobular breast carcinoma (41). ZEB2 is also a transcriptional factor implicated in regulation of EMT regulator. The significant association of ZEB2 expression with many other EMT-regulated markers including VIM, SNAI2/SLUG, TWIST2 in diffuse- vs. intestinalGC (Table IV) further indicates prominent mesenchymal features in diffuse GC. In a previous report, Ohta et al (33) 
Table IV. Statistical analysis and correlation between genes in the series of 13 diffuse/poorly cohesive gastric cancer.

A, Growth factors and receptors $(n=10)$

\begin{tabular}{|c|c|c|c|c|c|c|c|c|c|c|}
\hline \multirow[b]{2}{*}{ Genes } & \multicolumn{2}{|c|}{ IGF1 } & \multicolumn{2}{|c|}{ FGF7 } & \multicolumn{2}{|c|}{ CDH1 } & \multicolumn{2}{|c|}{ ZEB2 } & \multicolumn{2}{|c|}{ CXCR4 } \\
\hline & $\mathrm{r}$ & $\mathrm{P}$-value ${ }^{\mathrm{a}}$ & $\mathrm{r}$ & P-value ${ }^{a}$ & $\mathrm{r}$ & $\mathrm{P}$-value ${ }^{\mathrm{a}}$ & $\mathrm{r}$ & P-value ${ }^{a}$ & $\mathrm{r}$ & P-value ${ }^{a}$ \\
\hline IGF1 & 1.0 & $<0.0001$ & 0.670 & 0.012 & 0.533 & 0.061 & 0.797 & 0.0011 & -0.049 & 0.87 \\
\hline IGF2 & 0.335 & 0.26 & 0.599 & 0.031 & -0.170 & 0.58 & 0.528 & 0.064 & 0.467 & 0.11 \\
\hline IGF1R & 0.412 & 0.16 & 0.440 & 0.13 & 0.418 & 0.16 & 0.445 & 0.13 & 0.401 & 0.17 \\
\hline IGF2R & 0.434 & 0.14 & 0.088 & 0.78 & 0.901 & $<0.0001$ & 0.275 & 0.36 & 0.209 & 0.49 \\
\hline IRS1 & 0.407 & 0.17 & 0.539 & 0.058 & 0.407 & 0.17 & 0.385 & 0.19 & 0.363 & 0.22 \\
\hline IRS2 & 0.528 & 0.064 & 0.571 & 0.041 & 0.577 & 0.039 & 0.357 & 0.23 & 0.269 & 0.37 \\
\hline FGF7 & 0.670 & 0.012 & 1.0 & $<0.0001$ & 0.165 & 0.59 & 0.819 & 0.0006 & 0.126 & 0.68 \\
\hline FGFR1 & 0.610 & 0.027 & 0.786 & 0.0015 & -0.170 & 0.58 & 0.775 & 0.0019 & -0.313 & 0.30 \\
\hline ERBB2 & 0.429 & 0.14 & 0.368 & 0.22 & 0.676 & 0.011 & 0.462 & 0.11 & 0.198 & 0.52 \\
\hline ERBB3 & 0.434 & 0.14 & 0.500 & 0.082 & 0.478 & 0.099 & 0.522 & 0.067 & 0.396 & 0.18 \\
\hline
\end{tabular}

$\mathrm{B}$, EMT and migration $(\mathrm{n}=11)$

\begin{tabular}{|c|c|c|c|c|c|c|c|c|c|c|}
\hline \multirow[b]{2}{*}{ Genes } & \multicolumn{2}{|c|}{ IGF1 } & \multicolumn{2}{|c|}{ FGF7 } & \multicolumn{2}{|c|}{ CDH1 } & \multicolumn{2}{|c|}{ ZEB2 } & \multicolumn{2}{|c|}{ CXCR4 } \\
\hline & $\mathrm{r}$ & P-value ${ }^{a}$ & $\mathrm{r}$ & P-value ${ }^{a}$ & $\mathrm{r}$ & P-value ${ }^{a}$ & $\mathrm{r}$ & P-value ${ }^{a}$ & $\mathrm{r}$ & P-value ${ }^{a}$ \\
\hline VIM & 0.648 & 0.017 & 0.709 & 0.0067 & 0.341 & 0.25 & 0.764 & 0.0024 & 0.038 & 0.90 \\
\hline CDH1 & 0.533 & 0.061 & 0.165 & 0.59 & 1.0 & $<0.0001$ & 0.291 & 0.33 & 0.104 & 0.73 \\
\hline SNAI1 & 0.093 & 0.76 & -0.110 & 0.72 & 0.330 & 0.27 & -0.357 & 0.23 & 0.192 & 0.53 \\
\hline SNAI2 & 0.709 & 0.0067 & 0.670 & 0.012 & 0.423 & 0.15 & 0.830 & 0.0005 & 0.357 & 0.23 \\
\hline TWIST2 & 0.736 & 0.0041 & 0.830 & 0.0005 & -0.029 & 0.91 & 0.874 & $<0.0001$ & -0.302 & 0.32 \\
\hline TGFB1 & 0.302 & 0.32 & 0.528 & 0.064 & 0.104 & 0.73 & 0.555 & 0.049 & 0.374 & 0.21 \\
\hline RUNX3 & 0.341 & 0.25 & 0.643 & 0.018 & -0.132 & 0.67 & 0.560 & 0.046 & 0.396 & 0.18 \\
\hline ZEB2 & 0.797 & 0.0011 & 0.819 & 0.0006 & 0.291 & 0.33 & 1.0 & $<0.0001$ & 0.022 & 0.94 \\
\hline SIP1 & 0.149 & 0.63 & -0.182 & 0.55 & 0.234 & 0.44 & 0.080 & 0.80 & -0.374 & 0.21 \\
\hline CXCR4 & -0.049 & 0.87 & 0.126 & 0.68 & 0.104 & 0.73 & 0.022 & 0.94 & 1.0 & $<0.0001$ \\
\hline CXCL12 & 0.533 & 0.061 & 0.610 & 0.027 & -0.154 & 0.62 & 0.780 & 0.0017 & -0.352 & 0.24 \\
\hline
\end{tabular}

C, Cell proliferation and migration $(n=7)$

\begin{tabular}{|c|c|c|c|c|c|c|c|c|c|c|}
\hline \multirow[b]{2}{*}{ Genes } & \multicolumn{2}{|c|}{ IGF1 } & \multicolumn{2}{|c|}{ FGF7 } & \multicolumn{2}{|c|}{ CDH1 } & \multicolumn{2}{|c|}{ ZEB2 } & \multicolumn{2}{|c|}{ CXCR4 } \\
\hline & $\mathrm{r}$ & P-value ${ }^{a}$ & $\mathrm{r}$ & P-value ${ }^{a}$ & $\mathrm{r}$ & P-value ${ }^{a}$ & $\mathrm{r}$ & P-value & $\mathrm{r}$ & P-value ${ }^{a}$ \\
\hline MMP2 & 0.819 & 0.0006 & 0.720 & 0.0055 & 0.269 & 0.37 & 0.692 & 0.0087 & 0.055 & 0.86 \\
\hline MMP9 & 0.121 & 0.69 & 0.489 & 0.090 & 0.049 & 0.87 & 0.423 & 0.15 & 0.484 & 0.094 \\
\hline SPP1 & 0.071 & 0.82 & 0.313 & 0.30 & 0.137 & 0.65 & 0.022 & 0.94 & 0.489 & 0.090 \\
\hline CD44 & 0.571 & 0.041 & 0.225 & 0.46 & 0.170 & 0.58 & 0.264 & 0.38 & 0.016 & 0.96 \\
\hline RHOB & 0.203 & 0.51 & 0.121 & 0.69 & 0.016 & 0.96 & -0.132 & 0.67 & -0.203 & 0.51 \\
\hline RHOA & 0.335 & 0.26 & 0.038 & 0.90 & 0.643 & 0.018 & 0.137 & 0.65 & 0.214 & 0.48 \\
\hline MKI67 & 0.308 & 0.31 & 0.071 & 0.82 & 0.703 & 0.0073 & 0.038 & 0.90 & 0.005 & 0.99 \\
\hline
\end{tabular}

$D$, Angiogenesis $(n=6)$

\begin{tabular}{|c|c|c|c|c|c|c|c|c|c|c|}
\hline \multirow[b]{2}{*}{ Genes } & \multicolumn{2}{|c|}{ IGF1 } & \multicolumn{2}{|c|}{ FGF7 } & \multicolumn{2}{|c|}{ CDH1 } & \multicolumn{2}{|c|}{ ZEB2 } & \multicolumn{2}{|c|}{ CXCR4 } \\
\hline & $\mathrm{r}$ & P-value & $\mathrm{r}$ & P-value & $\mathrm{r}$ & P-value ${ }^{a}$ & $\mathrm{r}$ & P-value & $\mathrm{r}$ & P-value \\
\hline VEGF165 & 0.335 & 0.26 & 0.434 & 0.14 & 0.478 & 0.099 & 0.071 & 0.82 & 0.187 & 0.54 \\
\hline VEGF189 & 0.187 & 0.54 & 0.335 & 0.26 & 0.330 & 0.27 & 0.115 & 0.71 & 0.500 & 0.082 \\
\hline
\end{tabular}


Table IV. Continued.

$\mathrm{D}$, Angiogenesis $(\mathrm{n}=6)$

\begin{tabular}{|c|c|c|c|c|c|c|c|c|c|c|}
\hline \multirow[b]{2}{*}{ Genes } & \multicolumn{2}{|c|}{ IGF1 } & \multicolumn{2}{|c|}{ FGF7 } & \multicolumn{2}{|c|}{ CDH1 } & \multicolumn{2}{|c|}{ ZEB2 } & \multicolumn{2}{|c|}{ CXCR4 } \\
\hline & $\mathrm{r}$ & P-value ${ }^{a}$ & $\mathrm{r}$ & P-value & $\mathrm{r}$ & P-value ${ }^{a}$ & $\mathrm{r}$ & P-value ${ }^{a}$ & $\mathrm{r}$ & P-value \\
\hline FLT1 & 0.418 & 0.16 & 0.412 & 0.16 & 0.352 & 0.24 & 0.104 & 0.73 & 0.214 & 0.48 \\
\hline KDR & -0.330 & 0.27 & -0.121 & 0.69 & -0.071 & 0.82 & -0.286 & 0.34 & 0.313 & 0.30 \\
\hline VEGFC & 0.231 & 0.45 & 0.473 & 0.10 & 0.093 & 0.76 & 0.236 & 0.44 & -0.044 & 0.89 \\
\hline NRP1 & 0.681 & 0.010 & 0.802 & 0.0010 & 0.247 & 0.42 & 0.725 & 0.0050 & 0.044 & 0.89 \\
\hline
\end{tabular}

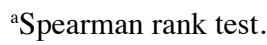

identified mesenchymal-like gene expression (including ZEB2, TWIST2 and SLUG) in diffuse-type GC and in gastric pit cells of gastric mucosa, indicating that the gastric pit cell exhibits the mesenchymal phenotype, and that diffuse-type GC also maintain it. Moreover, high ZEB2 expression was recently found to predict poor survival for digestive cancers using databases on 24 cohort studies (42).

In the present study, TGF $\beta 1$ expression (TGF $\beta 1$, another signal responsible for inducing EMT) was increased in both diffuse and intestinal GC. However, the expression levels of TGF $\beta 1$ do not permit discrimination between the two sub-populations GC with respect of EMT. This finding is deduced from -the absence of correlation between TGF $\beta 1$ and some EMT markers (CDHI, VIM, or SNAII) in diffuse GC, and -the finding that TGFß1, SNAII and SNAI2/SLUG are significantly increased in intestinal-type GC. Notably, $T G F \beta 1$ expression was significantly increased in a sub-population of diffusely infiltrating type of GC associated with extensive fibrosis (linitis) as compared with non-linitis diffuse GC. Our findings reinforce the documented role of $T G F \beta 1$ in stromal cells in aggressive GCs. We also found that TGF 1 expression was positively associated with expression of $M M P 9, P D 1$ and PDL2 (data not shown) in diffuse GC. These findings highlight the role of $T G F \beta 1$-signaling pathway in the tumoral stroma from diffuse GC, including stromal cells and the extracellular matrix. Wu et al (43) using a meta-analysis of patients with GC, have reported a $T G F \beta$-associated super module of stroma-related genes associated with diffuse-type histology and poor prognosis in patients with GC.

Little is known about the involvement of growth factors in GC and whether they are specific for a sub-population of GC. We show for the first time that expression of IGFI and $F G F 7$ are significantly increased in diffuse GC compared to non-tumoral gastric tissues and as compared with intestinal-subtype GC. Among the diffuse-gastric tumors, 77\% overexpressed $I G F I$ and $23 \%$ overexpressed FGF-7.

The IGF system promotes cancer proliferation, and its signalling induces the EMT phenotype which contributes to the migration, invasiveness and metastasis of epithelial tumors. IGFI expression was significantly increased in diffuse-subtype (x7.4, $\mathrm{P}=0.0004)$. The positive association of IGF1 expression with a set of mesenchymal marker and EMT regulator genes (VIM, SLUG, ZEB2 and TWIST2) indicates that $I G F I$ is associated with the EMT process in the diffuse-type GC. IGFI expression was also associated with the presence of lymph node in GCs. Using immunostaining, IGF1 protein was also detected in epithelial cells in gastric tumors (mainly diffuse-subtype). Previous studies have provided some evidence for the association of circulating IGF1 levels (and/or IGF binding proteins, IGFBPs) with cancer risk. Unfortunately, we had no gastric tumors samples (or plasma/serum) available to analyse circulating IGF1 levels (and/or IGFBPs) between these two types of GC in this cohort of patients, a potential limitation of the current study. Studies are needed to further assess the association between circulating IGF-1 level and GC risk.

We also show that $F G F 7$ expression is significantly increased $(\mathrm{P}<0.002)$ in diffuse-gastric tumors, while decreased in $31 \%$ of the intestinal-subtype. Most notably, FGF7 expression strongly correlated with the expression of FGFRI ( $\mathrm{P}=0.0001)$, some mesenchymal markers (VIM, ZEB2 and TWIST2), and genes expressed by the microenvironment (MMP2, NRP1). Our findings indicate for the first time an important role of FGF7 (a member of the fibroblast growth factor family) in diffuse-type GCs. Two studies have reported that FGF-7 is produced by mesenchymal cells in various tissues and cell lines which developed the characteristics of scirrhous carcinoma upon orthotopic implantation in mice $(26,44)$. Using immunocytochemistry, co-expression of FGF7 with MMP9 proteins has been previously associated with a poor prognosis in GC (45). Altogether, these findings suggest that patients with tumors that overexpress $F G F 7$ may be candidates for new target therapies, such as emerging FGFR-1 inhibitors.

Cell migration is dependent on the dynamic function and dis-sassembly of actin filament based structures, as well as cell-cell and cell-extracellular matrix adhesion. Decreased $\mathrm{CDH} 1$ expression, as well as increased $\mathrm{CXCR} 4$ expression was observed in the diffuse-subtype, leading to markedly reduced cell adhesion and increase of cellular motility, and resulting in tumor differentiation, invasiveness and metastasis. Differential gene expression of RHOA (highest in diffuse-type, as previously suggested by gain of function mutation (46), and $R H O B$ (lowest in intestinal-subtype) was observed for the first time in sub-populations of GCs. In the present study, CXCR4 expression is significantly up-regulated in diffuse subtype GC as 


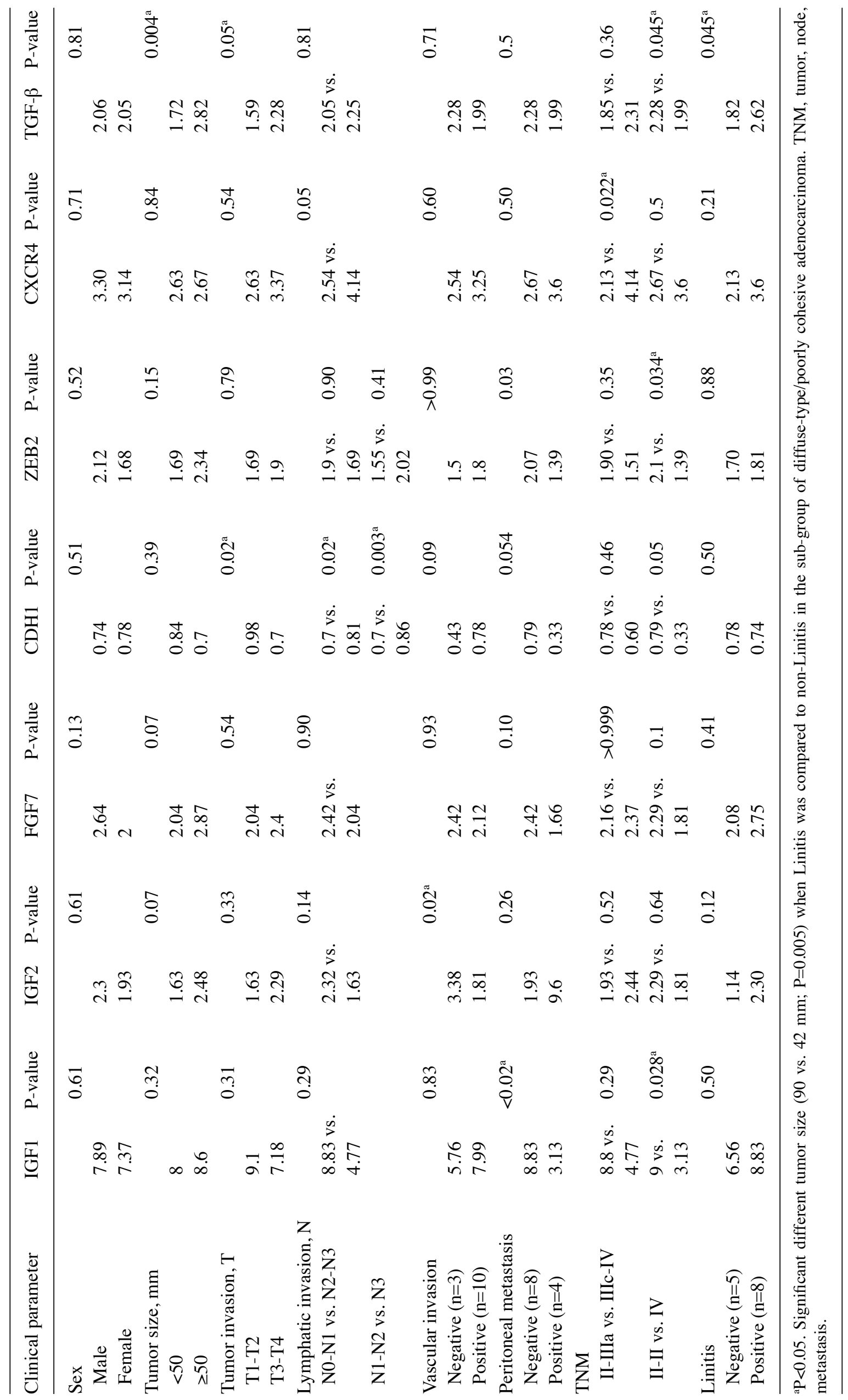



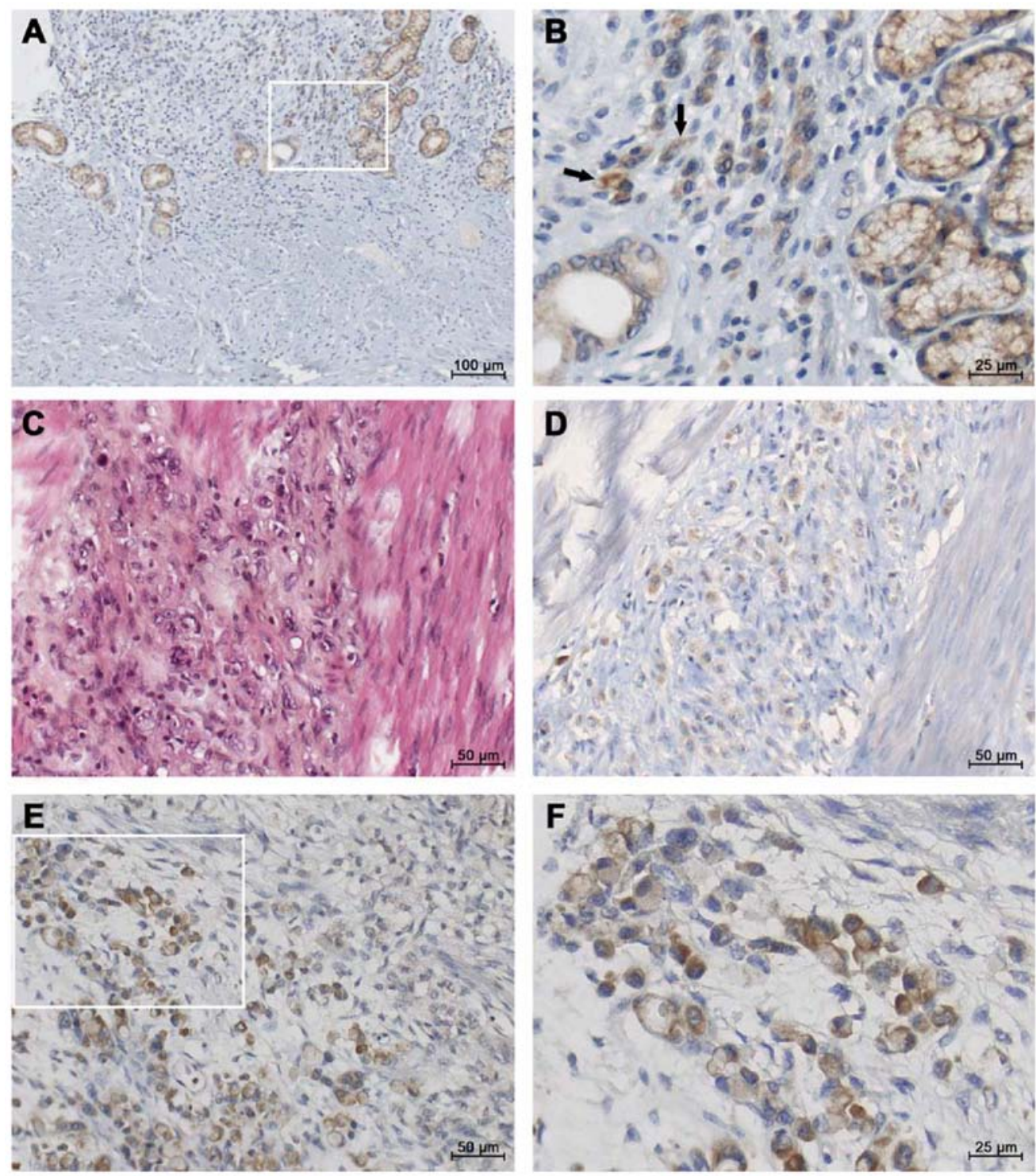

Figure 1. Representative micrographs of IGF1 immunohistotochemical staining in diffuse-GC. Paraffin sections from gastric tissues were incubated with polyclonal antibodies against IGF1. The figure presents IGF1 immunostaining in diffuse-GC with different stages of tumor invasion. (A and B) IGF1 staining in glandular and independent epithelial cells of the gastric sub-mucosa of a diffuse-type GC (TNM2b); inset: higher magnification. Arrows indicate independent IGF1 positive tumor cells. (C and D) Aggressive diffuse-GC associated with fibrosis (linitis, TNM4) in a young patient; (C) hematoxylin-eosin staining and (D) IGF1 staining in invasive tumor cells. (E and F) Strong IGF1 immunostaining in a metastatic diffuse carcinoma; inset: higher magnification. GC, gastric cancer; IGF1, insulin-like growth factor 1.

compared to intestinal-subtype, and is significantly associated with TNM (IIIc-IV, P=0.022) and lymphatic invasion. Various types of cancers including breast, prostate, brain, colon and lung overexpress levels of CXCR4 (47). On the other hand, our findings indicated a decreased CXCL12 expression in intestinal sub-type (not in diffuse sub-type) with respect to the corresponding normal tissue. Our findings complement recent studies on GCs (48-50), and suggest that CXCR4 overexpression in diffuse $\mathrm{GC}$ is a biomarker of this aggressive and infiltrating carcinoma. The nature of the chemokine which promotes invasiveness is not fully understood.

In conclusion, the present study presents evidence that tumor biomarkers represent a new approach to discriminate diffuse-type and intestinal-type GC. Several major signaling pathways have been often described in GC without discriminating the different subtypes. The majority of the studies in
GC have been conducted in Asia, so the conclusions should be taken cautiously when applied to other ethnic populations. In our series of European diffuse- GCs, we identified several candidate markers including growth factors (IGFI and $F G F 7$, and their receptors), ZEB2 (associated with VIM, SNAI2/SLUG and TWIST2), TGFB1 and CXCR4 involved in EMT, cell invasion and metastasis. We also emphasize the role of $T G F \beta 1$ as a main player of intratumoral remodeling, as exemplified by fibrosis. The relatively small number of tumors (30) could be a limiting factor and could bias for correlation and/or matching comparison. However, we obtained similar results when we compared tumoral tissue with normal tissue from the same patients. Our results also agree with the few genes previously reported in diffuse-GCs. Further studies with a larger cohort of gastric tumor samples and with different clinical characteristics (early and advanced 
stages of subpopulations) would offer opportunity to confirm genes of interest in diffuse-GCs.

\section{Acknowledgements}

The authors would like to thank Dr JP Brouland (Department of Pathology, Lariboisiere Hospital, Paris, France) for his assistance in GC histology and Mrs. C Marty (Lariboisiere Hospital) for her technical help.

\section{Funding}

The present study was supported by Institut National de la Santé et de la Recherche Medicale, Centre National de la Recherche Scientifique and ANSES (Agence Nationale de Securité sanitaire, Environnement, Travail, Maisons-Alfort, 94701, France).

\section{Availability of data and materials}

The datasets used and/or analyzed during the present study are available from the corresponding author on reasonable request.

\section{Authors' contributions}

MPA and IB contributed to the conception and design of the study. SV, CP, WC and MPA performed the experiments and statistical analysis. MP and SD conducted the GC biopsies and collected the clinical data from the patients. MPA drafted the manuscript.

\section{Ethics approval and consent to participate}

The present study was approved by the Ethical Committee of Lariboisiere Hospital (Paris, France). All patients provided written informed consent prior to their inclusion in the study.

\section{Patient consent for publication}

Not applicable.

\section{Competing interests}

The authors declare that they have no competing interests.

\section{References}

1. Ferlay J, Soerjomataram I, Dikshit R, Eser S, Mathers C, Rebelo M, Parkin DM, Forman D and Bray F: Cancer incidence and mortality worldwide: Sources, methods and major patterns in GLOBOCAN 2012. Int J Cancer 136: E359-E386, 2015.

2. Shi J, Qu YP and Hou P: Pathogenetic mechanisms in gastric cancer. World J Gastroenterol 20: 13804-13819, 2014.

3. Lauren P: The two histological main types of gastric carcinoma: Diffuse and so-called intestinal-type carcinoma. An attempt at a histo-clinical classification. Acta Pathol Microbiol Scand 64 31-49, 1965.

4. Watanabe H, Jass JR and Sobin LH: Histological Classification of Gastric Tumours. In: Histological typing of oesophageal and gastric tumors. World Health Organization. International Histological Classification of Tumours. Springer, Berlin, Heidelberg, 1990.
5. Hohenberger P and Gretschel S: Gastric cancer. Lancet 362: 305-315, 2003.

6. Alberts SR, Cervantes A and van de Velde CJ: Gastric cancer: Epidemiology, pathology and treatment. Ann Oncol 14 (Suppl 2): ii31-ii36, 2003.

7. Wu H, Rusiecki JA, Zhu K, Potter J and Devesa SS: Stomach carcinoma incidence patterns in the United States by histologic type and anatomic site. Cancer Epidemiol Biomarkers Prev 18: 1945-1952, 2009.

8. Henson DE, Dittus C, Younes M, Nguyen H and Albores-Saavedra J: Differential trends in the intestinal and diffuse types of gastric carcinoma in the United States, 1973-2000: Increase in the signet ring cell type. Arch Pathol Lab Med 128: 765-770, 2004.

9. Jézéquel J, Bessaguet C, Verveur C, Faycal J, Richert Z, Metges JP, Volant A, Nousbaum JB and Robaszkiewicz M: Trends in incidence, management, and survival of gastric and cardia carcinomas in the area of Finistere (France) between 1984 and 2003. Eur J Gastroenterol Hepatol 22: 1412-1419, 2010.

10. Ha TK, An JY, Youn HK, Noh JH, Sohn TS and Kim S: Indication for endoscopic mucosal resection in early signet ring cell gastric cancer. Ann Surg Oncol 15: 508-513, 2008.

11. Kim JP, Kim SC and Yang HK: Prognostic significance of signet ring cell carcinoma of the stomach. Surg Oncol 3: 221-227, 1994.

12. Hyung WJ, Noh SH, Lee JH, Huh JJ, Lah KH, Choi SH and Min JS: Early gastric carcinoma with signet ring cell histology. Cancer 94: 78-83, 2002.

13. Taghavi S, Jayarajan SN, Davey A and Willis AI: Prognostic significance of signet ring gastric cancer. J Clin Oncol 30: 3493-3498, 2012.

14. Gronnier C, Messager M, Robb WB, Thiebot T, Louis D, Luc G, Piessen $\mathrm{G}$ and Mariette C; FREGAT working group-FRENCH: Is the negative prognostic impact of signet ring cell histology maintained in early gastric adenocarcinoma? Surgery 154: 1093-1099, 2013.

15. Pernot S, Voron T, Perkins G, Lagorce-Pages C, Berger A and Taieb J: Signet-ring cell carcinoma of the stomach: Impact on prognosis and specific therapeutic challenge. World $\mathrm{J}$ Gastroenterol 21: 11428-11438, 2015.

16. Kim DY, Park YK, Joo JK, Ryu SY, Kim YJ, Kim SK and Lee JH: Clinicopathological characteristics of signet ring cell carcinoma of the stomach. ANZ J Surg 74: 1060-1064, 2004.

17. Li C, Kim S, Lai JF, Hyung WJ, Choi WH, Choi SH and Noh SH: Advanced gastric carcinoma with signet ring cell histology. Oncology 72: 64-68, 2007.

18. Voron T, Messager M, Duhamel A, Lefevre J, Mabrut JY, Goere D, Meunier B, Brigand C, Hamy A, Glehen O, et al: Is signet-ring cell carcinoma a specific entity among gastric cancers? Gastric Cancer 19: 1027-1040, 2016.

19. Uemura N, Okamoto S, Yamamoto S, Matsumura $\mathrm{N}$, Yamaguchi S, Yamakido M, Taniyama K, Sasaki N and Schlemper RJ: Helicobacter pylori infection and the development of gastric cancer. N Engl J Med 345: 784-789, 2001.

20. Smith BR and Stabile BE: Extreme aggressiveness and lethality of gastric adenocarcinoma in the very young. Arch Surg 144: 506-510, 2009

21. Messager M, Lefevre JH, Pichot-Delahaye V, Souadka A, Piessen G, Mariette C, Arnaud JP, Balon JM, Bonnetain F, Borie F, et al; FREGAT working group - FRENCH: The impact of perioperative chemotherapy on survival in patients with gastric signet ring cell adenocarcinoma: A multicenter comparative study. Ann Surg 254: 684-693, 2011.

22. Inoue K, Nakane Y, Kogire M, Fujitani K, Kimura Y, Imamura H, Tamura S, Okano S, Kwon AH, Kurokawa Y, et al: Phase II trial of preoperative S-1 plus cisplatin followed by surgery for initially unresectable locally advanced gastric cancer. Eur J Surg Oncol 38: 143-149, 2012.

23. Bass AJ, Thorsson V, Shmulevich I, Reynolds SM, Miller M, Bernard B, Hinoue T, Laird PW, Curtis C, Shen H, et al; Cancer Genome Atlas Research Network: Comprehensive molecular characterization of gastric adenocarcinoma. Nature 513: 202-209, 2014.

24. Guilford P, Hopkins J, Harraway J, McLeod M, McLeod N, Harawira P, Taite H, Scoular R, Miller A and Reeve AE: E-cadherin germline mutations in familial gastric cancer. Nature 392: 402-405, 1998.

25. Lei Z, Tan IB, Das K, Deng N, Zouridis H, Pattison S, Chua C, Feng Z, Guan YK, Ooi CH, et al: Identification of molecular subtypes of gastric cancer with different responses to PI3-kinase inhibitors and 5-fluorouracil. Gastroenterology 145: 554-565, 2013. 
26. Nakazawa K, Yashiro M and Hirakawa K: Keratinocyte growth factor produced by gastric fibroblasts specifically stimulates proliferation of cancer cells from scirrhous gastric carcinoma. Cancer Res 63: 8848-8852, 2003.

27. Washington K: 7th edition of the AJCC cancer staging manual: stomach. Ann Surg Oncol 17: 3077-3079, 2010.

28. Shu P, Qin J, Shen K, Chen W, Liu F, Fang Y, Wang X, Wang H, Shen Z, Sun Y, et al: The IGCA staging system is more accurate than AJCC7 system in stratifying survival of patients with gastric cancer in stage III. BMC Cancer 17: 238, 2017.

29. Sano T, Coit DG, Kim HH, Roviello F, Kassab P, Wittekind C, Yamamoto Y and Ohashi Y: Proposal of a new stage grouping of gastric cancer for TNM classification: International Gastric Cancer Association staging project. Gastric Cancer 20: 217-225, 2017.

30. Ji X, Bu ZD, Yan Y, Li ZY, Wu AW, Zhang LH, Zhang J, Wu XJ, Zong XL, Li SX, et al: The 8th edition of the American Joint Committee on Cancer tumor-node-metastasis staging system for gastric cancer is superior to the 7th edition: results from a Chinese mono-institutional study of 1663 patients. Gastric Cancer 21: 643-652, 2017.

31. Bièche I, Onody P, Laurendeau I, Olivi M, Vidaud D, Lidereau R and Vidaud M: Real-time reverse transcription-PCR assay for future management of ERBB2-based clinical applications. Clin Chem 45: 1148-1156, 1999.

32. Bieche I, Parfait B, Le Doussal V, Olivi M, Rio MC, Lidereau R and Vidaud M: Identification of CGA as a novel estrogen receptor-responsive gene in breast cancer: An outstanding candidate marker to predict the response to endocrine therapy. Cancer Res 61: 1652-1658, 2001.

33. Ohta H, Aoyagi K, Fukaya M, Danjoh I, Ohta A, Isohata N, Saeki N, Taniguchi H, Sakamoto H, Shimoda T, et al: Cross talk between hedgehog and epithelial-mesenchymal transition pathways in gastric pit cells and in diffuse-type gastric cancers Br J Cancer 100: 389-398, 2009.

34. Tanabe S, Aoyagi K, Yokozaki H and Sasaki H: Gene expression signatures for identifying diffuse-type gastric cancer associated with epithelial-mesenchymal transition. Int J Oncol 44: 1955-1970, 2014.

35. Phrakonkham P, Brouland JP, Saad HS, Bergès R, Pimpie C, Pocard M, Canivenc-Lavier MC and Perrot-Applanat M: Dietary exposure in utero and during lactation to a mixture of genistein and an anti-androgen fungicide in a rat mammary carcinogenesis model. Reprod Toxicol 54: 101-109, 2015.

36. Vacher S, Castagnet P, Chemlali W, Lallemand F, Meseure D, Pocard M, Bieche I and Perrot-Applanat M: High AHR expression in breast tumors correlates with expression of genes from several signaling pathways namely inflammation and endogenous tryptophan metabolism. PLoS One 13: e0190619, 2018.

37. Thomassen I, van Gestel YR, van Ramshorst B, Luyer MD, Bosscha K, Nienhuijs SW, Lemmens VE and de Hingh IH: Peritoneal carcinomatosis of gastric origin: A population-based study on incidence, survival and risk factors. Int J Cancer 134: 622-628, 2014

38. Humar B, Blair V, Charlton A, More H, Martin I and Guilford P. E-cadherin deficiency initiates gastric signet-ring cell carcinoma in mice and man. Cancer Res 69: 2050-2056, 2009.
39. Yang $\mathbf{J}$ and Weinberg RA: Epithelial-mesenchymal transition At the crossroads of development and tumor metastasis. Dev Cell 14: 818-829, 2008.

40. Kalluri R and Weinberg RA: The basics of epithelial-mesenchymal transition. J Clin Invest 119: 1420-1428, 2009.

41. Yang J, Mani SA, Donaher JL, Ramaswamy S, Itzykson RA, Come C, Savagner P, Gitelman I, Richardson A and Weinberg RA: Twist, a master regulator of morphogenesis, plays an essential role in tumor metastasis. Cell 117: 927-939, 2004

42. Chen H, Lu W, Huang C, Ding K, Xia D, Wu Y and Cai M Prognostic significance of ZEB1 and ZEB2 in digestive cancers: A cohort-based analysis and secondary analysis. Oncotarget 8: 31435-31448, 2017.

43. Wu Y, Grabsch H, Ivanova T, Tan IB, Murray J, Ooi CH, Wright AI, West NP, Hutchins GG, Wu J, et al: Comprehensive genomic meta-analysis identifies intra-tumoural stroma as a predictor of survival in patients with gastric cancer. Gut 62: $1100-1111,2013$

44. Takemura S, Yashiro M, Sunami T, Tendo M and Hirakawa K: Novel models for human scirrhous gastric carcinoma in vivo. Cancer Sci 95: 893-900, 2004.

45. Zhang Q, Wang P, Shao M, Chen SW, Xu ZF, Xu F, Yang ZY, Liu BY, Gu QL, Zhang WJ, et al: Clinicopathological correlation of keratinocyte growth factor and matrix metalloproteinase-9 expression in human gastric cancer. Tumori 101: 566-571, 2015.

46. Kakiuchi M, Nishizawa T, Ueda H, Gotoh K, Tanaka A, Hayashi A, Yamamoto S, Tatsuno K, Katoh H, Watanabe Y, et al: Recurrent gain-of-function mutations of RHOA in diffuse-type gastric carcinoma. Nat Genet 46: 583-587, 2014.

47. Zhao H, Guo L, Zhao H, Zhao J, Weng H and Zhao B: CXCR4 over-expression and survival in cancer: A system review and meta-analysis. Oncotarget 6: 5022-5040, 2015.

48. Izumi D, Ishimoto $\mathrm{T}$, Miyake $\mathrm{K}$, Sugihara $\mathrm{H}$, Eto $\mathrm{K}$, Sawayama H, Yasuda T, Kiyozumi Y, Kaida T, Kurashige J, et al: CXCL12/CXCR4 activation by cancer-associated fibroblasts promotes integrin $\beta 1$ clustering and invasiveness in gastric cancer. Int J Cancer 138: 1207-1219, 2016.

49. Qiao J, Liu Z, Yang C, Gu L and Deng D: SRF promotes gastric cancer metastasis through stromal fibroblasts in an SDF1-CXCR4-dependent manner. Oncotarget 7: 46088-46099, 2016.

50. Xiang Z, Zhou ZJ, Xia GK, Zhang XH, Wei ZW, Zhu JT, Yu J, Chen W, He Y, Schwarz RE, et al: A positive crosstalk between CXCR4 and CXCR2 promotes gastric cancer metastasis. Oncogene 36: 5122-5133, 2017.

This work is licensed under a Creative Commons

Attribution-NonCommercial-NoDerivatives $\quad 4.0$ International (CC BY-NC-ND 4.0) License. 